\title{
Changes in Chemical Components and Energy Charge during Growth Cycle of Chattonella antiqua
}

\author{
Shettapong Meksumpun, ${ }^{* 1}$ Shigeru Montani, ${ }^{* 1}$ Thaithaworn Lirdwitayaprasit, ${ }^{* 2}$ \\ Hiromi Sakamoto, ${ }^{* 1}$ Tadashi Ochi, ${ }^{* 1}$ and Tomotoshi Okaichi*1 \\ (Received February 8, 1993)
}

\begin{abstract}
The changes in cellular content of adenosine triphosphate (ATP) in Chattonella antiqua (Hada) Ono (Raphidophyceae), a red tide microorganism, were determined during growth in laboratory culture using ESM-enriched seawater. Carbon, nitrogen, and phosphorus in the cells were also analyzed. The cellular content of ATP decreased within several hours of inoculation into fresh medium, then rapidly increased during the early exponential phase of growth to $20-30 \mathrm{pg}$ ATP cell ${ }^{-1}$. After the mid exponential phase ATP decreased and reached a constant level from the late exponential phase to the stationary phase at 5-10 pg ATP cell ${ }^{-1}$. The decrease of ATP after inoculation seemed to be due to a lack of extracellular organic materials in the fresh medium. The addition of both low and high molecular fractions obtainned by dialysis from early stationary phase cultures of $C$. antiqua increased the cellular ATP content in the early exponential phase. The energy charge decreased from 0.63 to about 0.5 during the lag phase and recovered during the exponential phase. The lag phase in $C$. antiqua culture is the period of adaptation to fresh medium possibly by the production of extracellular organic materials at the expense of cellular ATP.
\end{abstract}

For two decades physiological and biochemical studies of the growth of Chattonella spp. have been conducted to understand the cause of the outbreaks of Chattonella red tides. The nutritional requirements of Chattonella spp. have been examined by Twasaki' and Nakamura et al. ${ }^{23}$ The biochemical mechanisms of iron absorption ${ }^{3)}$ and the role of vitamins ${ }^{4,5}$ have also been investigated. Recently it was reported that the adenosine triphosphate (ATP) content of dinoflagellates changes remarkably throughout the life cycle. ${ }^{8.7)} \mathrm{Me}$ ksumpun et al ${ }^{\mathrm{s})}$ also proposed that the amino acid contents in $C$. antiqua change markedly during the growth cycle.

Cellular contents of ATP are maintained at fairly uniform levels in various cells and tissues, indicating a very sensitive and efficient cellular mechanism for the control of ATP concentration. ${ }^{2)}$ However, in the case of Scrippsiella trochoidea, $\left.{ }^{6}\right)$ the ATP content decreases from $4.0 \mathrm{pg}$ ATP cell $^{-1}$ in the exponential phase to about $2.5 \mathrm{pg}$ ATP cell $^{-1}$ in the resting phase. It is interesting that the ATP content in marine phytoplankton cells may change with the phases of their growth cycles. Chapman et al. ${ }^{10}$ proposed that the physiological state of microorganisms could be expressed by the adenylate energy charge. The hypothesis that adenylate energy charge determines and defines the bioenergetic state of a living cell has been extended to phytoplankton. ${ }^{11-15)}$

We investigated the changes in the total cellular contents of carbon $(\mathrm{C})$, nitrogen $(\mathrm{N})$, phosphorus (P), and adenylic nucleotide in C. antiqua (Hada) Ono throughout its growth cycle in batch culture. The influences of small and large molecular fractions obtained from dialysis of $C$. antiqua culture medium on the ATP content of $C$. antiqua were also examined.

\section{Materials and Methods}

\section{Culture Conditions}

The axenic culture strain of $C$. antiqua was routinely grown in 300-m $l$ Erlenmeyer flasks containing $100 \mathrm{ml}$ of autoclaved $\left(120^{\circ} \mathrm{C}, 20 \mathrm{~min}\right)$ ESM-enriched seawater from the Seto Inland

* Department of Bioresource Science, Kagawa University, Miki, Kagawa, 761-07 Japan (Shettapong Meksumpun, 阴谷 茂, 坏本浩美, 越智 正, 岡书友利: 香川大学费学部).

*2 Marine Fisheries Division, Department of Fisheries, Yanawa, Bangkok, Thailand (Thaithaworn Lirdwitayaprasit: 夕イ水座局水窟海洋锞). 
Sea (salinity $31 \pm 1 \%$ ) without soil extract. ${ }^{10}$ ) Illumination was provided by cool-white fluorescent lamps at an irradiance level of approximately $80 \mu \mathrm{E} \mathrm{m}^{-2} \mathrm{~s}^{-1}$ with a $14: 10 \mathrm{~h} \mathrm{LD}$ cycle. The temperature was kept at $21 \pm 1{ }^{\circ} \mathrm{C}$. C. antiqua were grown in a $10-l$ glass carboy containing 9 liters of ESM-enriched seawater under the conditions described above. The samplings were performed $6 \mathrm{~h}$ after switching the fuorescent lamps on, except for the short-time experiments (48 hours long) which were carried out in two separate flasks. Cell number, cellular carbon, cellular nitrogen, cellular phosphorus, and cellular ATP and its related compounds were estimated. All samples were filtered through glass-filters (Whatman $\mathrm{GF} / \mathrm{C}$ freed of organic matter by ignition at $450^{\circ} \mathrm{C}$ for 2 hours) and stored at $-20^{\circ} \mathrm{C}$ till analysis, except for the samples used for cellular ATP and related compounds, which were extracted as described below.

\section{Determination of $A T P$ Content}

A one $\mathrm{m} l$ subsample from cultures of $C$. antiqua grown was taken at appropriate intervals for five weeks and added to $10 \mathrm{~m} /$ of boiling TRIS- $\mathrm{HCl}$ buffer $(0.025 \mathrm{M}, \mathrm{pH} 7.7)$. ATP extractions were done in triplicate. The extracted ATP was assayed using an SAI integration photometer, Model 2000

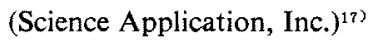

\section{HPLC Analysis of ATP and Related Compounds}

After the filtration had been completed on Whatman $\mathrm{GF} / \mathrm{C}$, the filters were immersed in boiling TRIS-HCl buffer $(0.025 \mathrm{M}, \mathrm{pH} 7.7)$ at $100^{\circ} \mathrm{C}$ to inactivate all the enzymes. The extracted samples were analyzed by reverse phase HPLC. The HPLC system was composed of a Shimadzu LC-9A HPLC pump and a Shimadzu SPD-6A UV spectrometer detector, using a wavelength of $260 \mathrm{~nm}$. The column was a Shimadzu shim-pack CLC ODS (M) analytical column $(250 \times$ $4.6 \mathrm{~mm}$ ID). The buffer used as eluent was $30 \mathrm{~mm}$ $\mathrm{NH}_{4} \mathrm{H}_{2} \mathrm{PO}_{4}$ containing $1.5 \mathrm{~mm} \mathrm{PIC}$ (tetrabutyl ammonium acetate) and $10 \%(\mathrm{v} / \mathrm{v})$ methanol $(\mathrm{pH}$ 7.2).

The energy charge (EC) was calculated after Chapman et al. $\left.{ }^{10}\right)$ as follows: $\mathrm{EC}=(\mathrm{ATP}+1 / 2$ ADP $) /($ ATP + ADP + AMP).

Effect of Extracellular Low and High Molecular Weight Fractions from Culture Medium on ATP Content

One hundred $\mathrm{m} l$ of medium, in which $C$, antiqua had been cultured for 30 days and reached a cell density of 15,000 cells $\mathrm{m} l^{-1}$, was filtered and dialyzed against 1 liter of distilled water for 24 hours. The fractions inside and outside of the dialysis membrane (approx. cut range molecular weight is $12,000-14,000$ ) were concentrated to $100 \mathrm{ml}$. Fifty $\mathrm{m} l$ of these solutions were added to $50 \mathrm{~m} l$ of fresh ESM medium. Ten $\mathrm{m} l$ of culture containing with cells at late exponential phase were inoculated into the flasks containing these media. The first subsampling was started $3 \mathrm{~h}$ after switching fluorescent lamps on. At appropriate intervals ATP and cell numbers were estimated.

Total Cellular Carbon, Nitrogen, and Phosphorus Analyses

The filtered samples were freeze dried. Carbon and nitrogen were measured by a Yanaco MT-3 $\mathrm{CHN}$ analyzer. Total cellular phosphorus was determined by the methods of Anderson et al. ${ }^{18)}$ and Strickland and Parsons. ${ }^{18)}$

\section{Results}

\section{Changes in Cellular ATP During Growth}

Chattonella antiqua grew in ESM-culture medium at a rate of 0.23 divisions/day during the first 14 days; during the early exponential phase it grew exponentially at a rate of 0.34 divisions/day. The changes in cellular ATP levels during growth are shown in Fig. 1. The cellular content of ATP was about $10-15 \mathrm{pg}$ ATP cell ${ }^{-1}$ during the first few days. The ATP pool of the cells was greatest during the early exponential phase of growth (25-

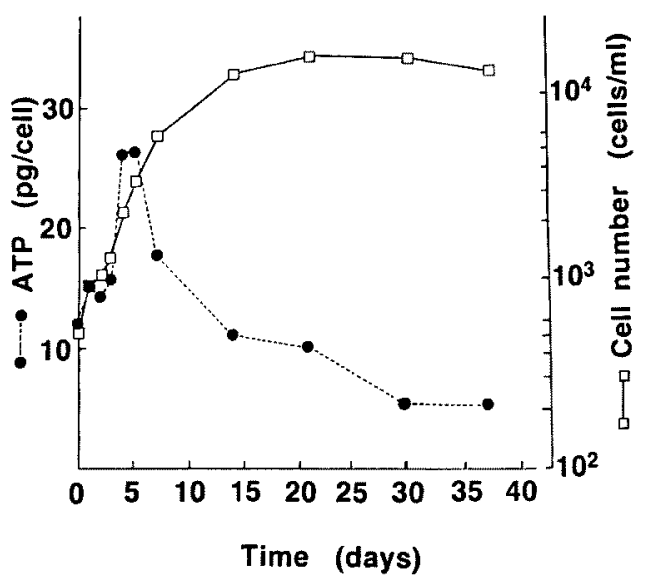

Fig. 1. Changes in cellular ATP during the growth of Chattonella antiqua. 


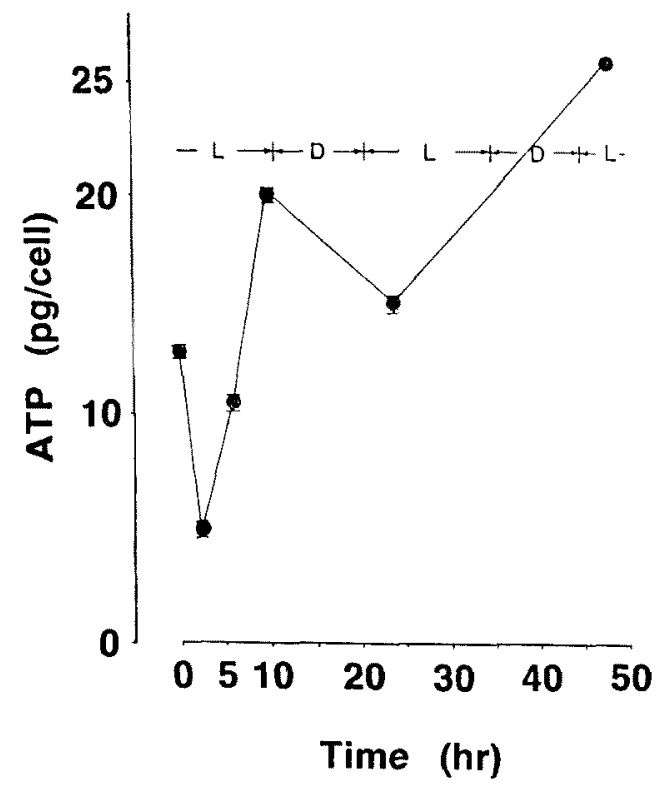

Fig. 2. Changes in cellular ATP in C. antiqua under light and dark conditions.

$30 \mathrm{pg}$ ATP cell ${ }^{-1}$ ). After that it decreased during the growth of the culture and seemed to reach a stationary level $\left(5-10 \mathrm{pg}\right.$ ATP cell $\left.^{-1}\right)$ in the late exponential phase.

The ATP pool of cells incubated in the light for 3 hours decreased to $5 \mathrm{pg}$ ATP cell-1 (Fig. 2). After incubation in the light for 10 hours, cellular ATP increased sharply to $20 \mathrm{pg}$ ATP cell ${ }^{-1}$.

HPLC Analysis of ATP and Related Compounds and Energy Charge

The patterns of changes in ATP, ADP, and AMP levels are shown in Fig. 3A. The cellular contents of ATP and ADP in C. antiqua increased during the early exponential phase. The AMP content was less than that of ATP and ADP. The energy charge of $C$. antiqua calculated from the HPLC analytical data decreased from 0.63 to 0.53 after 2 days and then increased to 0.59 after 4 days (Fig. 3B). It seemed to become virtually stable from the early exponential phase to the late exponential phase of growth, remaining at about 0.6 for 2 weeks. During the late stationary phase, the energy charge declined slowly to a value of about 0.5 .

Changes in Cellular Contents of Carbon, Nitrogen, and Phosphorus

The carbon content of $C$. antiqua varied between
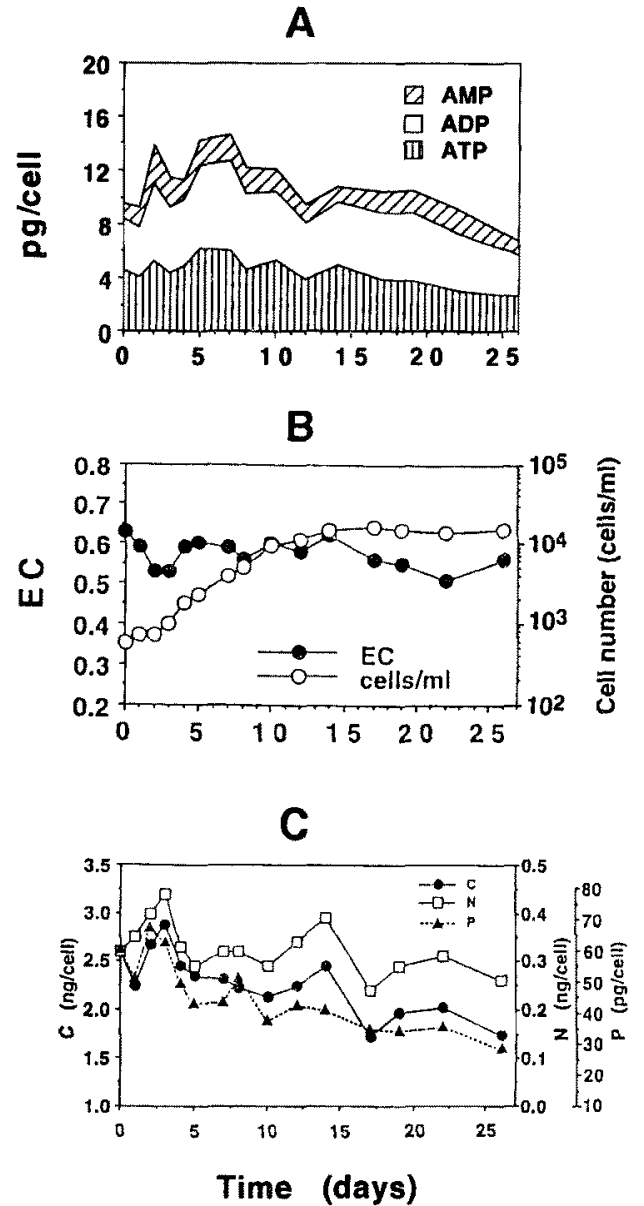

Fig. 3A. Changes in the cellular contents of nucleotides during the growth of $C$. antiqua.

Fig. 3B. Changes in the energy charge (EC) of C. antiqua during growth.

Fig. 3C. Changes in cellular carbon, nitrogen, and phosphorus during the growth of $C$. antiqua.

1.7 and $2.9 \mathrm{ng} \mathrm{cell}^{-1}$ throughout the growth of the culture (Fig. 3C). It increased remarkably during the early exponential phase of growth. Changes in cellular nitrogen followed the same general pattern as the changes in cellular carbon (Fig. 3C). After 3 days, the amount of nitrogen per cell had increased by about $40 \%$, and thereafter it decreased markedly. An increase occurred again when cells reached the mid exponential phase of growth. Total phosphorus levels increased from 59 to $67 \mathrm{pg} \mathrm{cell}^{-1}$ after the inoculation for two days. Then they decreased sharply until they 
reached a nearly constant level during the stationary phase (Fig. $3 \mathrm{C}$ ). The $\mathrm{C} / \mathrm{N}$ ratio during the growth was between 7 and 10 . This ratio decreased markedly during the lag and early exponential phases, after which it increased and then became more or less constant from the mid exponential phase to the end of the experiment. The changes in $\mathrm{C} / \mathrm{N}$ and $\mathrm{N} / \mathrm{P}$ ratios during the growth of $C$. antiqua are given in Table 1 . The ratio of $\mathrm{C}$ and $\mathrm{N}$ to $\mathrm{P}$ increased from the lag phase to the mid exponential phase. Thereafter, this ratio increased when cells reached the stationary phase. The ratio of phosphorus to carbon was slightly low compared to that of the Redifield number $(C: N$ : $P=106: 16: 1)^{20)}$ Holm-Hansen"1) proposed that algae ranging in size from $1 \mathrm{pg} \mathrm{C} /$ cell to $215000 \mathrm{pg}$ $\mathrm{C} / \mathrm{cell}$ had uniform levels of ATP relative to organic carbon (ATP $=0.35 \%$ organic carbon). In this study, the C/ATP ratios in C. antiqua were nearly constant throughout the growth cycle. The mean value of ATP of $C$. antiqua during the growth was $0.22 \%$ organic carbon, with C.V. of $11.2 \%$.

Effects of Extracellular Low and High Molecular Fractions on Cellular ATP Content

The ATP pools of cells in fresh ESM culture medium with the addition of $50 \mathrm{~m} /$ of low or high molecular weight fractions were remarkably higher than those of cells in control culture one day after inoculation (Fig. 4). ATP levels in cells exposed to the low molecular weight fraction increased greatly during the first day. The ATP pool of cells exposed to the high molecular weight fraction decreased after 3 hours, then increased markedly. After two days of inoculation, the cellular content of ATP in cells which were exposed to the low and high molecular weight fractions were higher than that of the control by about $80 \%$ and $100 \%$, respectively.

\section{Discussion}

The result in Figure 2 shows that the cellular content of ATP decreased within 3 hours of inoculation into fresh medium and then increased during the light period of the first day. Upon transfer to the new medium from an old culture containing extracellular substances, $C$. antiqua needs to adapt to the fresh medium, thus the consumption of ATP and the production of extracellular substances may occur. A biochemical lag phase refers to this period when ATP is being consumed in the fresh medium. The addi-

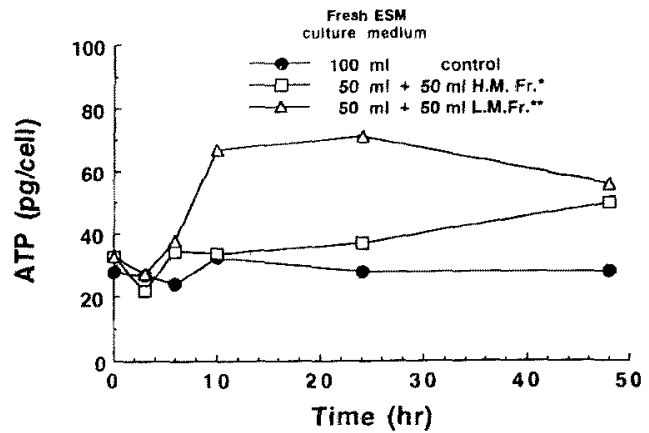

Fig. 4. Changes in cellular ATP in $C$, antiqua as influenced by high and low molecular weight fractions in fresh ESM culture medium.

*High molecular weight fraction

**Low molecular weight fraction

tion of extracellular substances to fresh medium prevents the decrease of intracellular ATP to a certain extent. Corresponding with the increase of ATP that occurs about 48 hours after inoculation, cell division accelerates and growth enters the exponential phase. During the early exponential phase ATP is kept at a constant high level. Thereafter, cellular ATP gradually decreases and reaches a constant low concentration during the late exponential and stationary phases. Lirdwitayaprasit et al..$^{B, 7}$ also reported that cellular contents of ATP of Alexandrium catenella and Scrippsiella trochoidea during the exponential phase were higher than those of the stationary phase when grown in the $\mathrm{PO}_{4}{ }^{3-}$ P-limited encystment medium.

In our study, ATP/cell measured by an ATP photometer was higher than that by the HPLC method. Although it is known that firefly luciferase is specific for ATP, it is likely that other molecules containing high energy phosphate bonds might cause some light emission. Holm-Hensen and Booth ${ }^{17}$ reported that ADP, CTP, and ITP had some effect on light emission. This reason may contribute to the occurrence of such a high estimation of ATP in cell as measured by the ATP-photometer.

Energy charge (EC) is generally recognized as a metabolic regulatory parameter. Chapman et al. ${ }^{10}$ found a correlation between $\mathrm{EC}$ and the growth state of Escherichia coli. active growth occurred only at EC values above 0.8 . Cells were viable at values between 0.8 and 0.5 , but died at values below 0.5 . Growth cut off sharply as the EC declined past a narrow critical range. ${ }^{23}$ Re cently, Salmeron et al. ${ }^{32}$ suggested that the EC 
Table 1. Changes in cellular $\mathrm{C}, \mathrm{N}, \mathrm{P}$ contents and $\mathrm{C} / \mathrm{N} / \mathrm{P}$ ratio during growth of Chattonella antiqua.

\begin{tabular}{ccccccc}
\hline $\begin{array}{c}\text { Time } \\
\text { (days) }\end{array}$ & $\begin{array}{c}\text { C/cell } \\
(\mathrm{pM})\end{array}$ & $\begin{array}{c}\text { N/cell } \\
(\mathrm{pM})\end{array}$ & $\begin{array}{c}\mathrm{P} / \mathrm{cell} \\
(\mathrm{pM})\end{array}$ & $\mathrm{C}: \mathrm{N}$ & $\mathrm{N}: \mathrm{P}$ & $\mathrm{C}: \mathrm{N}: \mathrm{P}$ \\
\hline 0 & 217 & 22.8 & 1.92 & 9.5 & 11.9 & $106: 11.1: 0.9$ \\
1 & 187 & 24.8 & 1.60 & 7.5 & 15.5 & $106: 14.1: 0.9$ \\
2 & 222 & 28.6 & 2.17 & 7.8 & 13.2 & $106: 13.6: 1.0$ \\
3 & 240 & 31.4 & 2.02 & 7.7 & 15.5 & $106: 13.9: 0.9$ \\
4 & 204 & 23.2 & 1.60 & 8.8 & 14.5 & $106: 12.1: 0.8$ \\
5 & 195 & 20.6 & 1.40 & 9.5 & 14.7 & $106: 11.2: 0.8$ \\
7 & 192 & 22.9 & 1.39 & 8.4 & 16.5 & $106: 12.6: 0.8$ \\
8 & 185 & 23.0 & 1.62 & 8.1 & 14.2 & $106: 13.2: 0.9$ \\
10 & 176 & 20.8 & 1.17 & 8.5 & 17.8 & $106: 12.5: 0.7$ \\
12 & 187 & 24.3 & 1.36 & 7.7 & 17.9 & $106: 13.8: 0.8$ \\
14 & 204 & 27.9 & 1.32 & 7.3 & 21.1 & $106: 14.5: 0.7$ \\
17 & 143 & 16.9 & 1.12 & 8.5 & 15.1 & $106: 12.5: 0.8$ \\
19 & 164 & 21.0 & 1.10 & 7.8 & 19.1 & $106: 13.6: 0.7$ \\
22 & 169 & 22.0 & 1.13 & 7.7 & 19.4 & $106: 13.8: 0.7$ \\
26 & 145 & 18.6 & 0.92 & 7.8 & 20.2 & $106: 13.6: 0.7$ \\
\hline
\end{tabular}

value of Azotobacter chroococcum was about 0.8 although cells were grown with a fixed nitrogen source or dinitrogen. Changes in light condition during night-sampling and extracting do not induce significant variations, in the adenylic nucleotide content or in EC values of microplankton. ${ }^{243}$ In our study, the EC value of $C$. antiqua decreased from 0.63 initially to 0.53 three days after inoculation, sharply increased to a stable value of about 0.6 during the exponential phase, and then decreased again when cells reached the stationary phase of growth. The decrease of the EC after inoculation into the fresh medium was probably due to the fact that cells were shocked by the new culture medium and subsampling on the first day. Riemann and Wium-Andersen ${ }^{12}$ also reported that the EC in nitrogen-depleted Periastrum duplex cells decreased for 2 days after the addition of nitrogen. Presumably a "lag effect" was caused by the transfer of the extreme nitrogen-deficient algae to the new nutrient regime. The value of EC remained low for about 3 days. This result suggests that the ATP in the cell was used for cell adaptation during this period. Thereafter, ATP/ cell increased markedly, probably because of the increase in cell activity. A decrease occurred again at the beginning of the stationary phase perhaps because of the decrease in metabolic activity, as reflected by the low levels of nitrogen and phosphorus in the cells. Reiman and Wium-Ander$\operatorname{sen}^{25)}$ reported that during the phosphorus deficiency (particulate $C / P \sim 85$ ) the $E C$ values of Selenastrum capricornutum, Scenedesmus acutus and Periastrum duplex were low (mean 0.54).
Starvation by removal of all sources of phosphorus introduced a decline in the $\mathrm{EC}$ value and the level of photosynthetic activity of Microcystis aeruginosa. ${ }^{14)}$

The amount of cellular carbon in $C$. antiqua increased sharply during the lag and the early exponential phases of growth, probably reflecting the increase in photosynthetic rate and the accumulation of new products such as carbohydrate, protein and lipid necessary for cell division, which accelerated rapidly after this period. This result coincided with the definition of lag phase which was referred to a period of restoration of enzyme and substrate concentrations to the levels necessary for rapid growth. ${ }^{26)}$ The amount of carbon per cell during the stationary phase was considerably lower than during the exponential phase, perhaps because of the low concentrations of nutrients in the culture medium and the reduction of cell activity.

During the lag phase and early exponential phases, the amount of nitrogen per cell increased by about $40 \%$ compared to its initial level. Moreover, the changes in cellular nitrogen followed the same general pattern as for cellular ATP. These results confirm that cells during these phases can increase their photosynthetic rate and accumulate the biochemical compounds necessary for cell division.

The level of cellular phosphorus in $C$. antiqua during the lag and the early exponential phases increased by more than $10 \%$ of its initial level. This level increased rapidly" reaching a maximum just 2 or 3 days after the inoculation, presumably 
reflecting a high rate of phosphorus absorption from the new culture medium for the production of ATP and other phosphorus compounds. The amount of phosphorus per cell of C. antiqua decreased about $30 \%$ between cells at the exponential and stationary phases. This is probably due to the low concentrations of nutrients in the culture medium and the reduction of cell activity. Cellular phosphorus of Heterosigma akashiwo increased during the growth processes and cells were able to continue their growth although the phosphorus in the culture medium was undetectable. ${ }^{27 .}{ }^{28}$ ) Lirdwitayaprasit et al. ${ }^{7)}$ also reported that cellular phosphorus of Scrippsiella trochoidea cultured in $\mathrm{PO}_{4}{ }^{3} \mathrm{P}$-limited encystment medium decreased about $40 \%$ between vegetative cells at the exponential and stationary phases of growth.

The means of $\mathrm{C} / \mathrm{N}$ raito of $C$. antiqua during the exponential phase and the stationary phase were not so different. However, this ratio decreased remarkably during the early exponential phase in which cell division accelerated. A linear relationship between the $\mathrm{C} / \mathrm{N}$ ratio and relative specific growth rate has been found in $\mathrm{N}$-limited chemostats for phytoplankton..$^{20-33)}$ Davidson et al..$^{34)}$ also reported that this relationship holds for non-steadystate growth in batch cultures.

Overall, these studies provide more detail about the changes in chemical components during the growth of $C$. antiqua. They show that after inoculation, the cells rapidly adjusted their biochemical conditions and accumulated chemical components for the preparation of cell division that increased rapidly after this period. Such a biochemical preparation in red tide organisms will also play an important role in the outbreak of red tides.

\section{Acknowledgments}

The authors wish to express their sincere thanks to the members of Laboratory of Marine Biochemistry and Marine Resources Chemistry, Kagawa University. The study is partly supported by the Grand-in-Aid for Scientific Research (60560219) from the Ministry of Education, Science, and Culture of Japan.

\section{References}

1) H. Iwasaki: Physiological ecology of red tide flagellates. in "Biochemistry and Physiology of Protozoa" (eds. by M. Levandowsky and S. H. Hunter), Vol. 1, Academic Press, New York, 1979, pp. 357-393.
2) Y. Nakamura, T. Umemori, and M. Watanabe: Chemical environment for red tides due to Chattonella antiqua. Part. 2. Daily monitoring of the marine environment throughout the outbreak period. J. Oceanogr. Soc. Japan, 45, 116-128 (1989).

3) T. Okaichi, S. Montani, J. Hiragi, and A. Hasui: The role of iron in the outbreaks of Chatronella red tide. in "Red Tides: Biology, Enivronmental Science, and Toxicology" (eds. by T. Okaichi et al.), Elsievier, New York, 1989, pp. $353-356$.

4) T. Nishijima and Y. Hata: Physiological ecology of Chattonella antiqua (Hada) Ono on B group vitamin requirement. Nippon Suisan Gakkaisht, 52, 181-186 (1986).

5) T. Nishijima and $Y$. Hata: The dynamics of vitamin $B_{12}$ and its relation to the outbreak of Chat tonella red tides in Harima Nada, the Seto Inland Sea, Japan. in "Red Tides: Biology, Environmental Science, and Toxicology" (eds. by T. Okaichi et al.), Elsevier, New York, 1989, pp. 257-260.

6) T. Lirdwitayaprasit, S. Nishio, S. Montani. and T. Okaichi: The biochemical processes during cyst formation in Alexandrium vatenella. in "Toxic Marine Phytoplankton" (eds. by E. E. Graneli et al.), Elsevier, New York, 1990a, pp. 294299.

7) T. Lirdwitayaprasit, T. Okaichi, S. Montani, T. Ochi, and D. M. Anderson: Changes in cell chemical composition during the life cycle of Scrippsiella trochoidea (Dinophyceae). J. Phycol., 26, 99-106 (1990b).

8) S. Meksumpun, S. Montani, and T. Okaichi: Changes in amino acid composition during cyst formation and quiescence of Chattonella antiqua. in "Toxic Phytoplankton Blooms in the Sea" (eds. by T. J. Smayda and Y. Shimizu), Elsevier, Amsterdam, 1993, pp. 147-152.

9) D. E. Atkinson: Regulation of enzyme function. Ann. Nev. Microbiol, 23, 47-68 (1969).

10) A. G. Chapman, L. Fall, and D. E. Atkinson: Adenylate energy charge in Escherichia coli during growth and starvation. J. Bact., 108. 1072-1086 (1971).

11) P. G. Falkowski: The adenylate energy charge in marine phytoplankton: The effect of temperature on the physiological state of Skeletonema costatum (Grev.) Cleve. J. Exp. Mar. Biol. Ecol., 27, 37-45 (1977).

12) B. Reimann and $S$. Wium-Andersen: Predictive value of adenylate energy charge for metabolic and growth states of planktonic communities. Oikos, 39, 256-260 (1982).

13) C. Videau: Primary production and physiological state of phytoplankton at the Ushant tidal front (west coast of Brit. tany, France). Mar. Ecol. Frog. Ser., 35, 141-154 (1987).

14) S. Hino: Variations in physiological states corresponding to cellular phosphorus content in freshwater phytoplankton: Correlations with adenylate energy charge and photosynthetic activity. Arch. Hydrobiol., 113, 295-305 (1988a).

15) S. Hino: Extracellular release of organic matter associated with the physiological state of freshwater bluegreen algae. Arch. Hydrobiol., 113, 307-317 (1988b).

16) T. Okaichi, S. Nishio, and Y. Imatomi: Mass culture of marine phytoflagellates, and approach to new sources of biologically active compounds, in "IUPAC Pesticide Chemistry" (eds. by J. Miyamoto and P. C. Kearney), Vol. 2., Pergamon Press, New York, 1983, pp. 141-144.

17) O. Holm-Hansen and C. R. Booth: The measurement of adenosine triphosphate in the ocean and its ecological signifcance. Limnol. Oceanogr., 11, 510-519 (1966).

18) D. M. Anderson, D. W. Coats, and M. A. Tyler: Encystment of the dinoflagellate Gymnodinium uncatenum: Temperature and nutrient effects. J. Phycol., 21, 200-206 (1985).

19) J. D. H. Strickland and T. R. Parsons: A practical handbook of seawater analysis. Fish. Res. Board. Can. Bull. No. 1671968,331 pp.

20) A. C. Redfield, B. H. Ketchum, and F. A. Richards: The influence of organisms on the composition of sea water, in "The Sea" (ed. by M. N. Hill), Vol. 2, Inter Science, 1963, 
$26 \mathrm{pp}$.

21) O. Holm-Hansen: ATP levels in algal cells a influenced by environmental conditions, Plant \& Cell Physiol., 11, 689700 (1970).

22) J. S. Swedes, R. J. Sedo, and D. E. Atkinson: Relation of growth and protein synthesis to the adenylate energy charge in an adenine requiring mutant of Escherichia coli. J. Biol. Chem, 250, 6930-6938 (1975).

23) V. Salmeron, M. V. Matinez-Taledo, and J. Gonzalez-Lopez: Effect of the nitrogen source on the adenine nucleotide content and energy charge of Azotobactor chroococcum. Chemosphere, 19, 1779-1786 (1989).

24) J. C. Romano: Impact of sampling on the adenylic nucleotide (ATP, ADP, AMP) content of microplankton. Variations in light conditions and contribution of zooplankton. Hydrobiologia, 121, 35-43 (1985).

25) B. Reimann and S. Wium-Andersen: The ATP and Total adenine nucleotide content of four unicellular and colonial green algae. Oikos, 36, 368-373 (1981).

26) G. E. Fogg: Algal cultures and phytoplankton ecology. The University of Wisconsin Press, London, 1965, $126 \mathrm{pp}$.

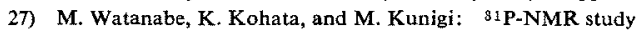
of intracellular phosphate pools and polyphosphate metabolism in Heterosigma akashiwo (Hada) Hada (Raphidophyceae). J. Phycol., 23, 54-62 (1987).

28) M. Watanabe, K. Kobata, and M. Kunigi: Phosphate ac- cumulation and metabolism by Heterosigma akashiwo (Raphidophyceae) during diel vertical migration in a stratified microcosm. J. Phycol., 24, 22-28 (1988).

29) K. L. Terry, J. Hirata, and E. A. Laws: Light-, nitrogen-, and phosphorus-limited growth of Pheaodactylum tricornutum Bohlin strain TFX-1: chemical composition, carbon partitioning, and diel periodicity of physiological processes. $J$. Exp. Mar. Biol. Ecol., 86, 85-100 (1985).

30) J. C. Goldman: On phytoplankton growth rates and particulate C: N: P ratios at low light. Limnol. Oceanogr., 31, $1358-1363$ (1986).

31) R. Herzig and P, G. Falkowski: Nitrogen limitation in Isochrysis galbana (Haptophyceae). I. Photosynthetic energy conversion and growth efficiencies. J. Phycol., 25, $462-471$ (1989).

32) M. S. Chalup and E. A. Laws: A test of assumption and predictions of recent microalgal growth models with the marine phytoplankter Pavlova lutheri. Limnol. Oceanogr., $35,583-596(1990)$.

33) M. R. Heath, K. Richardson, and T. Kiorboe: Optical assesment of phytoplankton nutrient depletion. J. Plankton. Res., 12, 381-396 (1990).

34) K. Davidson, K.J. Flynn, and A. Cunningham: Relationships between photopigments, cell carbon, cell nitrogen and growth rate for a marine nanoflagellate. J. Exp. Mar. Biol. Erol., 153, 87-96 (1991). 